\title{
THE ENGLISH R COMING! THE NEVER ENDING STORY OF PORTUGUESE RHOTICS
}

\author{
JOÃO VELOSO
}

\section{RESUMO}

Os róticos são provavelmente a classe consonântica do português que conheceu o maior número de mudanças no último século. A literatura costuma referir as observações de Viana $(1883,1903)$ a propósito do início do processo de substituição gradual da vibrante múltipla alveolar pela vibrante múltipla uvular. Neste artigo, tentamos identificar e datar outras mudanças, verificadas posteriormente, que vieram alterar a configuração e a organização geral das vibrantes do português: (i) na subclasse das vibrantes múltiplas, referiremos a introdução de consoantes fricativas (e, nas variedades brasileiras da língua, das consoantes glotais também) para o lugar do rótico uvular que iniciou o processo de entrada no português no final do século XIX; (ii) na subclasse das vibrantes simples, referiremos a emergência das variantes retroflexas, admitidas para o português do Brasil há já algumas décadas (principalmente, em resultado da variação sociolinguística) e que, no português europeu, parece começar a instalar-se a partir da fala de jovens escolarizados de alguns centros urbanos. Estes dados encontram suporte em alguns estudos recentes e, como será posto em destaque no presente texto, no corpus do Arquivo Dialetal do Centro de Linguística da Universidade do Porto.

I am glad to contribute a few notes on a phonetic/phonological subject to a volume offered to Belinda Maia, who is definitely not fond of this area. May it be read as a sign of my esteem and admiration for Belinda and her work. The chapter is focused on Belinda's "affective" (not second, definitely not foreign) language, Portuguese, and suggests that Portuguese phonology might be undergoing a relatively subtle influence from English (the introduction of retroflex flaps). This could be viewed as a meaningful simile of the "good vibes" (good vibrations and inspiring vibrantes) many Portuguese academics have received from Belinda during the last decades, even if not working directly with her or within her main topics of study. My English is not so gracious and fluent as Belinda's Portuguese, and I apologise to readers for that. I am sure some computer programmer working with Belinda will one day, sooner or later, create a special software to correct Academic English as obscure and vicious as mine. Linguistics and its applications are a never ending story, too, as anyone who knows Belinda is very much aware of. 


\section{[1] INTRODUCTION}

The main aim of this study is to analyse the main changes that have been taking place in the organization of the rhotics' system of Portuguese in the last century, broadly speaking.

The first of such changes was the introduction of a uvular trill ([ $\mathrm{R}])$, replacing the traditional Romance trill (alveolar [ $\mathrm{r}]$ ), which started towards the end of the $19^{\text {th }}$ century, perhaps as a phonemic borrowing from French.

That is not the end of the story, as we shall see, and many subsequent changes have taken place since then. I will propose that the most recent of such changes is the emergence of a retroflex flap ([ $r])$ - in short, "Belinda's R" -, which is becoming more and more frequent in certain phonological contexts and under given sociolinguistic conditions, maybe as the result of another phonemic borrowing, now from English. Different varieties of Portuguese - with special emphasis on European and Brazilian Portuguese - will be taken into consideration.

I will divide my text into three parts: in section [2], I shall concentrate on the (supposedly) first steps of the changes that will be considered here and try to formulate the main questions to be analysed; in section [3], a brief description of the rhotics' systems of European and Brazilian Portuguese will be given; section [4] will focus on some ongoing changes that can be observed in Contemporary Portuguese. A section with some final remarks will end the chapter.

\section{[2] THE First MAJOR CHANGE: THE EMERGENCE OF "Vicious" [R]}

\section{[2.1] $R U[\mathrm{r}]$ or $[\mathrm{R}]$ ?}

In 1883 and 1903, Gonçalves Viana, the "father" of Portuguese modern phonetics, wrote about the (then) recent introduction of a new rhotic in European Portuguese: the uvular trill [ $\mathrm{R}$ ], which, according to him, was gradually replacing the original Romance $[\mathrm{r}$ ], described by the author as the most original, most genuine, still most expanded in his century's language (Viana 1883, pg. 20; 1903, pg. 19).

In his colourful, suggestive language, Gonçalves Viana depicts what nowadays should be described, in sociolinguistic terms, as an ongoing change, obeying the main features of most sound changes in the world's languages: it had had a sudden start among urban (supposedly educated) speakers, it had a sociolinguistic motivation (it is reasonable to assume that its introducers wanted to sound "more cosmopolitan" and "more sophisticated" ${ }^{1}$ ), and, little by little, it spread to new speakers' communities:

[1] Contrastingly, Barbosa (1983, pg. 193) denies that [R ] was a direct borrowing from French and that it corresponded to a "prestigious" articulation, on the basis of the following main arguments: (i) there is no evidence that the change had originated in the Royal circles, in spite of frequent marriages between Portuguese princes and French princesses, (ii) the French adjective "vicieux", used by Viana (1903), has a very negative meaning, and (iii) similar changes took place in other languages, suggesting that phonetic rather than sociolinguistic variables were the real triggers of the phenomenon. 
"La prononciation uvulaire de $r$, mais non pas de - $r$-, comme $\mathbf{R}$, se répand de plus en plus dans les villes. Cependant, on la regarde encore comme vicieuse, le rr apical étant toujours préférable au grasseyement du $\mathbf{R}$, qui individuellement est plus profond qu'en français ou en allemand."

(Viana 1903, pg. 19; my italics)

Indeed, in the space of a few decades, uvular $[\mathrm{R}]$ became the standard trill of European Portuguese. It is confirmed by observations found in the most authoritative grammatical and phonological descriptions of the language (Barbosa $1983^{2}$; 1994; Barroso 1999; Mateus \& D'Andrade 2000; Mateus et al. 2003; Emiliano 2009), which give it as the Portuguese unmarked vibrante múltipla ${ }^{3}$, confining the alveolar trill [r] (i.e., the original trill of Portuguese, common to most Romance languages) to a minority of speakers (see, e.g., Mateus et al. 2003, pg. 1000).

So, it seems quite reasonably safe to assume that, from a purely phonological, descriptive point of view, / $\mathrm{R} /$ might be considered as the most recent - the youngest - phonemic segment of European Portuguese ${ }^{4}$. Its admission to the phonological system of the language was relatively fast and, to some extent at least, socially motivated, as suggested above.

\section{[2.2] Further questions regarding the diachronic changes of Portuguese rhotics}

As hinted at above, the "birth of / $/$ / in European Portuguese", as witnessed by Viana $(1883,1903)$, is not the last step of the recent historical changes involving Portuguese rhotics. In this section, it is my aim to highlight some further devel-

[2] Barbosa (1983) is a reprint of his 1965 publication.

[3] "Vibrante múltipla" (approximately, "multiple rhotic") is perhaps the most common term to designate (alveolar and uvular) trills in Portuguese, whereas "vibrante simples" (@ "simple rhotic") is preferably used to label taps/flaps (also regardless of their places of articulation).

[4] Whether the contrast surface $[\mathrm{R}]$ (or $[\mathrm{r}]$ ) vs. [ $\mathrm{r}]$ corresponds or not to a phonemic, underlying contrast opposing two different phonemes of the language has been debated by several authors. According to Barbosa (1994, pg. 146) and Mateus \& D'Andrade (2000, pgs. 15-16), for example, the phonemic inventory of Portuguese contains one single rhotic, $/ \mathrm{r} /$ : trills are always the surface, strictly phonetic result of a gemination process ([R $]=/$. . $]$ ). Câmara (1977, pgs. 78-79) (contradicting some of his previous assumptions) and Bonet \& Mascaró (1997), on the contrary, defend the existence of a lexical, underlying opposition between a phonological flap and a phonological trill - thus, the existence of two distinct (and distinctive) phonemes, in Portuguese, such as $/ \mathrm{r} / \neq / \mathrm{R} /$. Although this is a very important question for the phonological description of Portuguese, I will not deal with it in this study. 
opments that have taken place within the subsystem of Portuguese rhotics ${ }^{5}$ since such early observations. In part, these developments could even lead us to question the appropriateness of insisting to look upon rhotics as a true "natural class" in Portuguese, although such a discussion will not be developed in this paper.

In the following sections of this chapter, I will focus on two different, though inter-related, issues concerning the rhotics of Portuguese. I will try to show that the changes that are referred to by Viana $(1883,1903)$ or by Barbosa $(1983)$ are just a part of a story involving important changes that have altered not only the phonetic nature of European Portuguese trills, but that have also affected the other subclass of Portuguese rhotics - flaps -, both in the European varieties of Portuguese and in other, non-European dialects of the language. That is to say, the changes that Viana $(1883,1903)$ identified with respect to the emergence of an uvular trill $[R]$ gradually replacing the alveolar $[\mathrm{r}]$ should most likely be seen just as the first step of a major historical change altering the whole system of rhotics in this language. Some of its effects are still taking place in Contemporary Portuguese. In the development of these observations, I shall concentrate on two main specific questions:

- what has happened to Portuguese trills since Viana's (1903) vicious [ R ]?

- what is happening, in the current stage of the language, within the specific subset of Portuguese flaps?

In this analysis, data from both European and Brazilian Portuguese (EP and BP, respectively) will be taken into consideration; a brief mention will also be made of another variety of Portuguese, spoken in the Atlantic island of São Tomé.

\section{[3] THE ORGANISATION OF RHOTICS IN MODERN PORTUGUESE}

In this section, I shall start by giving a general overview of how rhotics are organized within the consonant system of Portuguese, not paying special attention to

[5] For the sake of simplicity and terminological ease, "rhotics" is used throughout this chapter as a phonetically/phonologically motivated class of sounds and as an appropriate label to name them. Nevertheless, it is borne in mind that it is extremely difficult to identify a set of stable characteristics that keep such sounds objectively apart as a specific phonetic/phonological class. The following words by Ladefoged \& Maddieson (1996) illustrate this issue very clearly; note that the authors point out, as the singularity which most probably is the main privative feature shared by all members of this class, the (extralinguistic, accidental) fact that "rhotic" sounds are written with Roman $\langle\mathbf{r}\rangle$ or Greek $\langle\rho\rangle$, and practically nothing else: "This chapter describes the class of sounds that are sometimes labeled 'rhotics', or more informally, ' $r$-sounds'. Most of the traditional classes referred to in phonetic theory are defined by an articulatory or auditory property of the sounds, but the terms rhotic and $r$-sound are largely based on the fact that these sounds tend to be written with a particular character in orthographic systems derived from the GrecoRoman tradition, namely the letter ' $r$ ' or its Greek counterpart rho. The International Phonetic Alphabet provides a wide selection of symbols based on plain, rotated, turned or otherwise modified lower-case and capital versions of the letter ' $\mathrm{r}$ ', including $\mathrm{r}, \mathrm{r}, \mathrm{x}, \mathrm{r}, \mathrm{f}, \mathrm{R}, \mathrm{s}, \mathrm{I}[\ldots]$ ' (Ladefoged \& Maddieson 1996, pg. 215). For additional information regarding the discussion about the motivation of rhotics as a "natural class", see the arguments by Ladefoged \& Maddieson (1996) referred to in footnote 6. 
the historical and variationist data that form the core of this study.

Supposedly, rhotics form a special class of consonants, belonging to the subset of sonorants in Portuguese. From a phonetic point of view, they are usually voiced and formed by a brief contact (or a short series of brief contacts) between two articulators within the oral cavity ${ }^{6}$. This brief contact is not enough to cause real obstruction of the airflow, though, and as such it does not give rise to any inharmonic noise component.In fact, from a phonetic point of view, these consonants show high levels of harmonic energy and spectrographic patterns which make them very similar to vowels and glides (Lindau 1985, pg. $160 \mathrm{ff}$; Ladefoged \& Maddieson 1996, pg. $215 \mathrm{ff}$.). In close relation to this, they have high degrees of inherent sonority, which, in turn, makes them prone, in most languages, to occur in syllable codas and, in a significant number of languages, too, as syllabic nuclei. In a rather simplified SPE fashion, they are [+cons], [+son] (being distinguished from other sonorants, in the standard model of generative phonology, by the negative marks [-nas], [-lat]). In languages like Portuguese, they correspond to [-syll], whereas, in languages like Czech, Sanskrit and others (perhaps English), they can receive the mark [+syll].

A common distinction that is found in many languages - at least, in the description of many languages - keeps rhotics formed by one single contact of two oral articulators (=flaps or taps) apart from those where a series of rapid contacts of this kind takes place within a very short time window (=trills).

In Modern European Portuguese (henceforth: MEP), it is traditionally assumed that rhotics contrast at the surface level $^{7}$ : one flap, allegedly invariant and common to all speakers, phonetically realized as coronal [ $r$ ], vs. one trill. This contrast occurs word-medially, in pairs such as the ones found in example (1); the main question which is most often mentioned has to do with the trill's phonetic realization. As said before, according to the literature, in MEP the standard trill is the voiced uvular [ $\mathrm{R}$ ] (that is to say, Gonçalves Viana's prophecy has been fulfilled!), whilst alveolar [ $\mathrm{r}$ ] still survives in a minority of speakers (Barbosa 1983, 1994; Barroso 1999; Mateus \& D'Andrade 2000; Mateus et al. 2003; Emiliano 2009). This is the main reason why I chose $[R]$, instead of $[r]$, to transcribe all the trills in example (1).

[6] "The most prototypical members of the class of rhotics are trills made with the tip or blade of the tongue (IPA r). These central members of the class show phonological relationships to the heterogeneous set of taps, fricatives and approximants which form the remainder of the class. In addition to tongue tip and blade articulations, trills and other continuants made at the uvular place are also classed as rhotics. [...] It is not therefore the manner of articulation that defines this group of sounds. Neither is there a particular place involved, as both Coronal and Dorsal articulations are included. Consequently an issue for phoneticians is whether the class membership is based only on synchronic and diachronic relationships between the members of the class, or whether there is indeed a phonetic similarity between all rhotics that has hitherto been missed. [...] " (Ladefoged \& Maddieson 1996, pgs. 215-216; my italics).

[7] As for the arguable phononological status of these surface contrasts, see again footnote 4. 
(1) Surface contrasts opposing flaps and trills in Modern European Portuguese aranha 'spider' [ $e$ 'regne ] - arranha '[he/she] scratches' [ $e$ ' вели ]

fora 'outside' [ 'fore ] - forra '[he/she] lines' [ 'fore ]

era '[it] was' ['Ere ] - erra '[he/she] commits a fault' ['ERQ ]

fera 'ferocious animal' [ 'fere ] - ferra '[it] bites' [ ffere ]

\section{[4] ONGOING CHANGES AND VARIATION IN PORTUGUESE RHOTICS}

After the general survey given in the previous section with the essentials about rhotics as a specific class of sounds, in Portuguese and other languages, I will return to the specific topic of this paper and on the data that were mentioned in the introduction: the ongoing changes that have been affecting Portuguese rhotics for several decades.

In this section, as previously announced, my observations will be split into two main directions: trills (again...) and taps.

[4.1] An even more vicious trill: in Portuguese, sonorant rhotics are becoming (phonetically) non-sonorants (fricatives and glottals)!

I began this chapter by recalling how Viana $(1883,1903)$ sounded so critical about the changing of $[\mathrm{r}$ ] into $[\mathrm{R}$ ], which seemed to be completely accomplished within a few decades, as outlined above.

In this section, I shall draw our attention to a further development of this phonetic change. In fact, what is particularly interesting to notice, nowadays, is that the "innovative" $[R]$ seems to be undergoing a subsequent, more drastic change in Portuguese. In fact, a growing number of speakers are replacing $[\mathrm{R}]$ by a fricative - that is to say, by an obstruent, typically behaving not as a sonorant, but more similarly to, say, a stop or an affricate, acoustically speaking -, within a range of choice which includes, in EP, velars (unvoiced $[\mathrm{x}]$ or voiced $[\mathrm{\gamma}]$ ) and uvulars (unvoiced $[\chi]$ and voiced $[\mathrm{s}]$ ).

Even though these realisations are not yet fully recognized as "phonemes", or at least as the most common or standard allophones of the Portuguese vibrante múltipla, several phonological descriptions of EP admit explicitly its occurrence and its frequency. Barbosa (1994, pg. 107) identifies Barbosa's (1983) work as the first to have ever noticed the emergence of a phonetic fricative in the place of a phonological vibrante. Barbosa's (1983) exact words are as follows: ${ }^{8}$

[8] Following a non-IPA convention which used to be very common among Portuguese linguists just a few decades ago, Barbosa (1983) transcribes the uvular trill as $/ \rho /$ (after the Greek letter $\langle\rho\rangle$, rho), instead of $/ \mathrm{R} /$. 
"En ce qui concerne la constrictive $[\mathrm{x}][. .$.$] comme étant l'une des$ réalisations possibles de $/ \rho /$, on ne dispose pas d'éléments qui permettent d'en dater les origines. Gonçalves Viana a écrit que quelquefois il prononçait 'le $r$ initial comme une fricative sonore, une espèce de $r z$ (non pas $r z ̌$ comme le $r z$ polonais)', en ajoutant qu'il avait 'rarement trouvé cette particularité dans la prononciation d'autres individus portugais."'

(Barbosa 1983, pg. 192)

Therefore, we cannot exclude the possibility that the emergence of a sort of fricative in this phonological context had already begun in the transition between the $19^{\text {th }}$ and $20^{\text {th }}$ centuries, but it surely became more apparent and more widespread in the mid-20 th century. Turning our attention to European Portuguese only, we can note that authors other than Barbosa $(1983,1994)$ also have observed the frequent realization of $/ \mathrm{R} / \mathrm{as}$ a fricative (either voiced or unvoiced, either velar or uvular): see, e.g. Barroso (1999) and Mateus \& D'Andrade (2000)

As for Brazilian authors describing the Brazilian varieties of Portuguese, it is commonplace to assume that the fricative - and, even more shocking perhaps for Gonçalves Viana's ears if he could listen to them, glottal - realizations of BP vibrantes múltiplas have almost entirely replaced the sonorant trills. Such an interpretation of the linguistic data may be found, for instance, in Silva (2002), who includes the fricatives $[\chi]$ (unvoiced) and $[\gamma]$ (voiced) and the glottals $[\mathrm{h}]$ (unvoiced) and [ $f]$ (voiced) in the set of the possible phonetic realizations of the intervocalic $\langle\mathrm{rr}\rangle$ of arranha '[he/she] scratches' (MEP, standard: [ $е$ ' велnе ] - see (1)).

In the data collection of dialectal variation of MEP belonging to the Centre of Linguistics of the University of Porto ${ }^{9}$ all the fricative, tap and trill forms are attested in European Portuguese ${ }^{10}$ (see also Rennicke \& Martins (2013)).

According to Rennicke \& Martins' (2013) careful analysis of the data held in the Arquivo, the scale of frequency of the / $\mathrm{R} /$-realizations in the Arquivo's corpus are as follows:

(2) Frequency scale of the phonetic realizations of phonological trills of Modern European Portuguese in the corpus of the Arquivo Dialetal do Centro de Linguística da Universidade do Porto (ap. Rennicke \& Martins 2013):

$$
\begin{gathered}
{[\mathrm{в}]} \\
(76 \%)
\end{gathered}>\underset{(24 \%)}{[\chi]}>\underset{(16 \%)}{[\mathrm{x}]}>\underset{(11 \%)}{[\mathrm{r}]}>\underset{(11 \%)}{[\mathrm{R}]}
$$

[9] Arquivo Dialetal do Centro de Linguística da Universidade do Porto (henceforth: "Arquivo"). It covers a considerable amount of sound samples, recorded since 1994 and duly described, analyzed and transcribed, mostly produced by young, educated speakers from the main Northern cities of Portugal (Veloso \& Martins 2013; Rennicke \& Martins 2013).

[10] The complete list of annotated phenomena is available at the corpus' webpage: http://cl.up.pt/ arquivo/como/tabela_fenomenos.pdf. 
Very interestingly, all these data show:

(i) That the "vicious" [ $\mathrm{R}$ ] that Viana (1903) identified as the most spreading in $19^{\text {th }}$ century Portuguese is, in the current stage of the language, the least represented allophone of the phonological "multiple trill", with the same percentage of occurrence that is found for its direct competitor in Viana's $(1883 ; 1903)$ writings (the original Romance alveolar trill [ r ], which has not completely disappeared from spoken Portuguese);

(ii) That fricatives seem to be, at the current stage of EP, the most representative realizations of Portuguese rhotics: according to these data, $[\mathrm{B}]$ is by far the most frequent of the trill allophones. This corroborates the previously mentioned impressionistic observations of Barbosa $(1983,1994)$, Barroso (1999) and Mateus \& D'Andrade (2000);

(iii) That BP has gone one step further in this change, replacing rather unanimously all phonetic trills by fricatives (like in EP) and by glottals as well, as it is the case for BP (Silva 2002).

So far, on the basis of all the data that were taken into consideration here, we could trace a rough chronology and "genealogy" of Portuguese trills (3).

(3) Portuguese trills (EP and BP) since the early observations by Gonçalves Viana (Viana 1883, 1903):

$$
\begin{aligned}
& \text { Pre and early } 19^{\text {th }} \text { century }\left\{\begin{array}{l}
\text { Alveolar Trill } \\
/ \mathrm{r} /
\end{array}\right. \\
& 19^{\text {th }}-20^{\text {th }} \text { century }\left\{\begin{array}{l}
\text { Uvular Trill } \\
/ \mathrm{R} /
\end{array}\right. \\
& \left\{\begin{array}{l}
\text { EP: Fricatives } \\
{[\mathrm{s}]>[\chi]>[\mathrm{x}]} \\
\text { (Rennicke \& }
\end{array}\right. \\
& 20^{\text {th }} \text { century to current stage } \\
& \text { (Rennicke \& Martins' (2013) } \\
& \text { frequency scale) } \\
& \text { BP: Fricatives and glotals } \\
& {[\chi, \mathrm{\gamma}, \mathrm{h}, \mathrm{h}]} \\
& \text { (Silva 2002) }
\end{aligned}
$$

NB: / $\mathrm{r} /$ and /R/ have not disappeared completely from Modern EP or Modern BP (see information in the text itself). In the table, only the innovative allophones are considered on the timeline according to the supposed date of their emergence in the language. 
The main conclusion to be drawn from these data and arguments is that the story and the history of Portuguese trills does not end with Viana's (1903) observations; from that moment onwards, other changes have altered the inventory and the relations between phonemic segments and their allophonic realizations within this class. The most drastic of the recent changes affecting this phonetic subclass has been the emergence of fricatives (and, in BP, of glottals, too) as phonetic counterparts of phonemic segments generally assumed as sonorant rhotics, in a way that can be found, quite strikingly, in other languages as well (as it seems to be the case of Italian, according to Ladefoged \& Maddieson (1996, pg. 219)).

\section{[4.2] Trills Are Not The End Of The Story, Yet. Retroflex Flaps, Or "Belinda's R"}

I shall now focus on another side of the story of rhotics' change in Portuguese: the emergence of a retroflex flap ([ $r]$ ), occurring in the place of the alveolar flap (supposedly invariant across all the speakers of EP (=[ $r])$, according to the literature).

To my knowledge, only a few previous studies refer to the existence of this "new" flap in EP, in addition to the phonetic transcriptions of the Arquivo's materials (under the responsibility of Pedro Tiago Martins) ${ }^{11}$, which identify - and transcribe - a large number of realizations of $/ \mathrm{f} /$ as an "approximant retroflex" ([ $][]$ ). Rennicke \& Martins (2013, pg. 520), based on their analysis of the same corpus, are certainly among the first studies to acknowledge such phonetic realization in EP. None of the aforementioned authoritative phonological descriptions of EP phonology - see, for instance, Barbosa $(1983,1994)$, Barroso (1999), Mateus \& D'Andrade (2000), Mateus et al. (2003) - even acknowledge the existence of this consonant in EP.

The lack of reference to a retroflex flap in such phonological descriptions of EP contrasts with the work of Rennicke \& Martins (2013) and with a careful analysis of the materials made available by the Arquivo; it also contrasts with my own strong linguistic intuitions. As a native speaker of Portuguese in daily contact with the Northern varieties of the language, mainly with the varieties spoken in Oporto by young, educated speakers, and as an attentive linguist particularly keen on variation phenomena, my impression is that a retroflex $[r]$ (maybe $[\tau]$ ) is becoming more and more common among these groups of speakers in the city of Oporto. It seems to be more frequent among young, educated female speakers than among males. Its rough distributional pattern seems to be the following: retroflex flap occurs mainly in syllabic codas (very seldom in onsets), most often in stressed word-final position (examples: professor 'professor' [pruf'sor]; fazer 'to do' [fe'zer] ]; amor 'love' [e'mor]).

[11] The phonetic transcriptions found in the Arquivo's website (http://cl.up.pt/arquivo) were subject to a double-checking verification and validation, according to the Inter-Judge Agreement methodology as described by Martins \& Veloso (2012). 
If this intuition proves correct - as the Arquivo's materials and the study by Rennicke \& Martins (2013) suggest - we could be witnessing a phenomenon quite similar to the one Viana $(1883,1903)$ described regarding the emergence of $[R]$ about one hundred years ago. Some parallelisms between the two changes should be highlighted here:

- both may have started as urban innovations;

- most likely, both result from a "phonemic borrowing" phenomenon: [ R ] could have been borrowed from French, the dominant foreign language among educated Portuguese in the $19^{\text {th }}$ century (even though Barbosa (1983, pg. 193), as seen above, disagrees with this interpretation); [ $\mathrm{r}$ ] could probably be the result of a borrowing from English, the main foreign language among Portuguese educated youngsters.

Actually, $[\tau]$ and $[\tau]$ are also the most frequent realizations of $/ r /$ by foreign learners and speakers of Portuguese who have English as their mother tongue.

As for retroflex flaps in BP, they behave differently from EP retroflex flaps. First of all, and contrary to what happens among Portuguese authors, many phonological descriptions of BP explicitly refer to a retroflex variant of flaps (see, for instance, and among many others: Netto 2001, pg. 99-100; Silva 2002, pg. 34, 49; Rennicke 2011). The main reason for this probably resides in a series of interrelated facts:

- retroflex realizations of flaps in BP are much more widespread than in EP, and occur in a larger number of prosodic contexts (stressed and unstressed, final and non-final syllables; filling either syllable onsets or codas). This contributes to making this realization more salient from a perceptual point of view;

- in addition to the spread of retroflexion, retroflex flaps have for a long time been socially identified, often stigmatized, with a specific speech style generally associated with non-urban, low-educated speakers; it even has a current specific designation: "R caipira" (="caipira R", "caipira" meaning, in a slightly judgmental way, an inhabitant from the most remote rural areas of the country, typically characterized by low degrees of education ${ }^{12}$ ).

As for this particular topic, we can conclude that, whereas retroflex $[\mathrm{r}]$ is emerging in $\mathrm{EP}$, even if completely ignored by the most prominent phonologists of this variant of the language, it has been a common phonetic realization in BP

[12] Nevertheless, the current geographic and social distribution of retroflex flaps in BP is much more widespread; it is very often heard in urban contexts and produced by highly educated speakers of the language (see, e.g., Rennicke 2011). 
for some time as recognized by the phonological descriptions regarding this variant $^{13}$.

\section{[5] FINAL REMARKS}

To conclude, we could say that Portuguese rhotics are perhaps the consonants which have been undergoing the most stunning phonetic and phonological changes for the last decades. Viana's $(1883 ; 1903)$ and Barbosa's $(1983)$ remarks about the emergence and stabilization of an uvular trill [ $\mathrm{R}$ ] following the historical $[\mathrm{r}$ ] have to be viewed as the first steps in a process which is not yet completely accomplished.

Linguistic, social and geographical factors seem to interact in the sound changes and substitutions that have been taking place for more than one century. At the present moment, no one can be entirely sure how the "story of Portuguese R" will really end and phonologists should pay special attention to a theoretical issue that will arise from the following steps of the process: given the desonorantization of trills (mostly realized as [-son] fricatives, in EP and BP, and also as glottals, in $\mathrm{BP}$ ), and bearing in mind that they are acquired differently from flaps in some prosodic contexts (Almeida 2011; Amorim 2014), will it make sense to insist on postulating a class of rhotics in Portuguese? This is a question that is left for future research.

To sum up, I include a final table putting together all the attested changes affecting all rhotics of Portuguese - trills and flaps - in the two main varieties of Portuguese (EP and BP). In a way, this table completes the one given in (3), which included trills only.

\section{ACKNOWLEDGMENTS}

I thank Diana Santos for the invitation and encouragement to publish in this volume. Thanks are also due to Pedro Tiago Martins, who read and commented an early draft of this text and corrected some parts of it. Part of this research was funded by Portugal's Fundação para a Ciência e a Tecnologia, through CLUP, the Centre of Linguistics of the University of Porto (Strategic Project PEstOE/LIN/UI0022/2014).

[13] Quite interestingly, some varieties of Portuguese show opposite tendencies, towards a fortition of flaps, which become (uvular) trills. This is the case of some varieties spoken around the Portuguese city of Setúbal (Southern dialects) and of São Tomé Portuguese (STP), where flaps do not exist at all. In the segmental positions where in other varieties a flap is expected, speakers articulate an uvular [ $\mathrm{R}$ ] (examples:

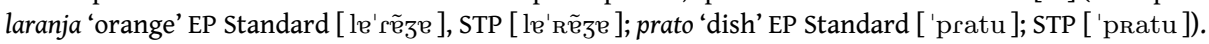


(4) Change of Portuguese rhotics (EP and BP) since the early observations by (Viana 1883, 1903).

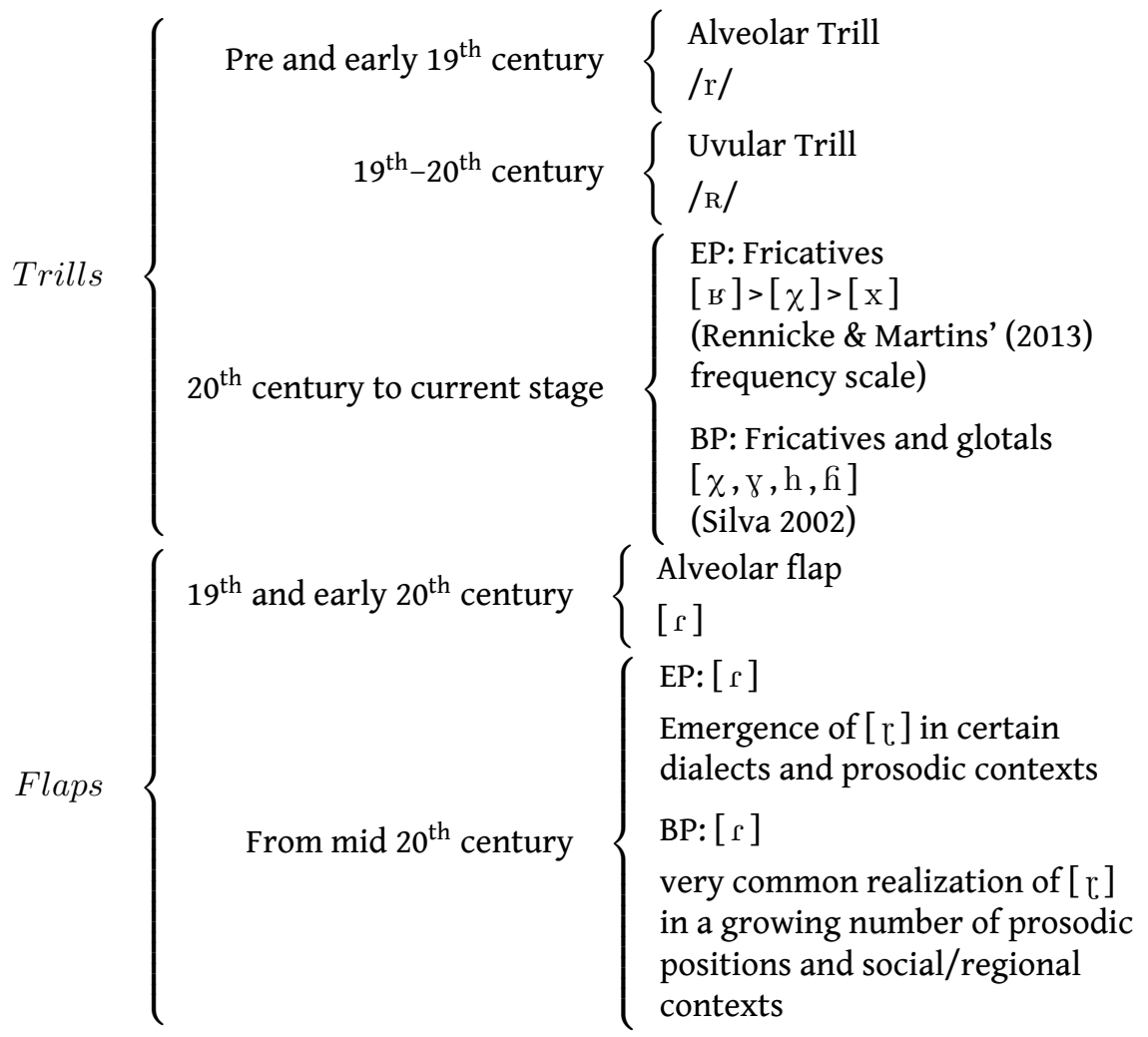

NB:

(i) $[r],[r]$ and $[R]$ have not disappeared completely from Modern EP or Modern BP (see information in the text itself). In the table, only the innovative allophones are considered on the timeline according to the supposed date of their emergence in the language.

(ii) No specific assumption is made about the exact date of emergence of [ $r$ ] in EP or BP. It is hypothesized that it emerged, in EP, sometime in the $20^{\text {th }}$ century, given the lack of explicit references to this realization, especially in studies regarding this variant of the language.

(iii) In BP, according to many sources, both trills and flaps can be completely deleted $(/ / R / />\varnothing)$ in some speech styles and under some prosodic conditions. Such deletion is also possible, less frequently and affecting only / $\mathrm{f} /$, in EP (e.g., in a final stressed syllable before a word with an initial consonant: falar baixo 'to keep his/her own voice down' [fe'la(f)bajsu ]). 


\section{REFERENCES}

Almeida, Letícia. 2011. Acquisition de la structure syllabique en contexte de bilinguisme simultané portugais-français: University of Lisbon Phd dissertation.

Amorim, Clara. 2014. Padrão de aquisição de contrastes do PE: a interação entre traços, segmentos e sílabas: University of Porto Phd dissertation.

Barbosa, Jorge Morais. 1983. Etudes de Phonologie Portugaise. Universidade de Évora 2nd edn.

Barbosa, Jorge Morais. 1994. Introdução ao Estudo da Fonologia e Morfologia do Português. Almedina.

Barroso, Henrique. 1999. Forma e Substância da Expressão da Língua Portuguesa. Almedina.

Bonet, E. \& J. Mascaró. 1997. On the representation of contrasting rhotics. In F. Martínez-Gil \& A. Morales-Front (eds.), Issues in the Phonology and Morphology of the Major Iberian Languages, 103-126. Georgetown University Press.

Câmara, Joaquim Mattoso. 1977. Para o Estudo da Fonêmica Portuguesa. Padrão.

Emiliano, António. 2009. Fonética do Português Europeu. Descrição e Transcrição. Guimarães.

Ladefoged, Peter \& Ian Maddieson. 1996. The Sounds of the World's Languages. Oxford.

Lindau, Mona. 1985. The story of /r/. In Victoria A. Fromkin (ed.), Phonetic Linguistics: Essays in honor of Peter Ladefoged, Academic Press.

Martins, Pedro Tiago \& João Veloso. 2012. Inter-Judge Agreement in Transcribing Dialectal Data: A Study of a Corpus of Dialectal Portuguese.

Mateus, Maria Helena \& Ernesto D'Andrade. 2000. The Phonology of Portuguese. Oxford University Press.

Mateus, Maria Helena Mira, Ana Maria Brito, Inês Duarte, Isabel Hub Faria, Sónia Frota, Gabriela Matos, Fátima Oliveira, Marina Vigário \& Alina Villalva. 2003. Gramática da Língua Portuguesa. Caminho 5th edn.

Netto, Waldemar Ferreira. 2001. Introdução à Fonologia da Língua Portuguesa. Hedra.

Rennicke, Iiris. 2011. The retroflex $\mathrm{r}$ of Brazilian Portuguese: theories of origin and a case study of language attitudes in Minas Gerais. Linguística. Revista de Estudos Linguísticos da Universidade do Porto 6(1). 149-170. 
Rennicke, liris \& Pedro Tiago Martins. 2013. As realizações fonéticas de /R/ em português europeu: análise de um corpus dialetal e implicações no sistema fonológico. In F. Silva, I. Falé \& I. Pereira (eds.), Textos Selecionados do XXVIII Encontro Nacional da Associação Portuguesa de Linguística. Coimbra: Associação Portuguesa de Linguística, 509-523. Associação Portuguesa de Linguística.

Silva, Thaïs Cristófaro. 2002. Fonética e Fonologia do Português. Roteiro de Estudos e Guia de Exercícios. Contexto 6th edn.

Veloso, João \& Pedro Tiago Martins. 2013. O Arquivo Dialetal do CLUP: disponibilização on-line de um corpus dialetal do português. In F. Silva, I. Falé \& I. Pereira (eds.), Textos Selecionados do XXVIII Encontro Nacional da Associação Portuguesa de Linguística, 673-692. Associação Portuguesa de Linguística.

Viana, Aniceto dos Reis Gonçalves. 1883. Essai de phonétique et de phonologie de la langue portugaise d'après le dialecte actuel de Lisbonne. Romania 12. 29-98.

Viana, Aniceto dos Reis Gonçalves. 1903. Portugais. Phonétique et phonologie. Morphologie. Textes. Teubner.

CONTACTS

João Veloso

Faculdade de Letras, Univerisdade do Porto

jveloso@letras.up.pt 